\title{
Richard Kostelanetz Interviews Kenneth Burke
}

Edited by J. Clarke Rountree III

KENNETH BURKE is the dean of eccentric American people of letters, perhaps the eldest survivor of a tradition that includes Gertrude Stein and Ezra Pound - writers so original and idiosyncratic that they could be born and raised only in America. As unusual in his lifestyle as in his writing, Burke lives where he has always lived for the past sixty years, amid a jumble of renovated barns, small farmhouses, garages and outhouses in northern New Jersey, within communications range of New York City, but as far away culturally as the Midwest. His age notwithstanding, he lives alone, taking care of himself in a small house that looks like a thousand others from the outside, but on the inside resembles a literary bachelor's pad, with books and papers strewn about and a piano in the middle.

Kenneth Duva Burke was born 5 May 1897 in Pittsburgh, PA. He attended the local public high school, where his classmates included Malcolm Cowley, and then briefly took classes at Ohio State and Columbia universities. He began publishing poems in 1916, fiction in 1917 and critical essays in 1921, always in literary magazines, and has since then been the epitome of the successful little magazine writer, whose work is so unslick it could never be mass-merchandised. Most of the books he has published are actually collections - of poems, fictions and essays; and among the most prominent titles are Counter-Statement (1931), The Philosophy of Literary Form (1941), and The Language as Symbolic Action (1966) - all of which are classified as literary criticism - and then Collected Poems, 1915-1967 (1968) and The Complete White Oxen: Collected Short Fiction (1968). There are yet other books, likewise collections, that are so wideranging and cross-circuited they are unclassifiable by conventional standards; they really deserve a shelf of their own, appropriately labeled Burkology: Permanence and Change (1935), Attitudes Toward History (1937), A Grammar of Motives (1945), $A$ Rhetoric of Motives (1950), $A$ Rhetoric of Religion: Studies on Logology (1961), and Dramatism and Development (1972). At last count, all his books were in print. Few writers are so fortunate.

Though he married young, and had three daughters by his first wife, and then two sons by a second wife (who was the first wife's sister), Burke 
did not get a permanent teaching position until he was forty-six - at Bennington College, teaching English on alternate weeks until his retirement in 1961; and he has since his retirement there accepted lectures and residencies around the country. His second wife died in 1969.

The man himself is short, compactly built, with a trim Van Dyke beard. On the day we met he was wearing farmer's clothes and preparing to go south, to a residency at a southern university to escape, as he put it, "the ten damnedest weeks of winter." From time to time he sipped vodka and vermouth. His speech is as singular as everything else about himpungent, slangy, splenetic, informal, elliptical, all serviced by a booming, raspy voice, with a profoundly American accent. Since it was the middle of winter, in a house that laçked central heating (just as it lacked electricity and telephone service until the late 1950s and plumbing until the late 1960s), we gravitated to its warmest room, the kitchen, where we spent the entire afternoon, except for a brief tour of his compound. To one and all, he has always been, and will always be, known as "KB." The interview took place early in 1981.

R.K.: You were born in Pittsburgh. What was your life like there?

K.B.: I was an only child. My father worked at Westinghouse, which shadowed the whole town. The way things were in those days, you were always broke. Dad was a minor clerk in a detail and supply department; he had one of those jobs where you were laid off periodically. I still hate Christmas because all I remember about Christmas is when I didn't get a damn thing because he would be laid off.

R.K.: What were your parents' backgrounds?

K.B.: Both my parents were raised in Pittsburgh. They were both Protestant. Their parents were immigrants. My mother's side was French and German. My father's side was Irish and German.

R.K.: Was your father an intellectual sort?

K.B.: He would have been wonderful if he'd had a good education. He had a great deal of ability, he was a wonderful raconteur, and he had a beautiful tenor voice. But, he was worried about me because I wasn't enough interested in making money. That was his thing; he spent his whole life under a cloud of a million dollars. All his life he was planning this and planning that. He was always inventing things, working on new ideas.

R.K.: Did you finish high school in Pittsburgh? 
K.B.: Yes, Peabody High School. It was a great public school. I studied two years of Greek there; you can't always take Greek in a university these days! My Greek teacher was a Harvard man. He taught in the high school because the pay was better than at the Western University of Pennsylvania (which became the University of Pittsburgh). Malcolm Cowley went to school there as well.

R.K.: What did you do after you graduated from Peabody?

K.B.: I went out to Ohio State for one term. A teacher at Peabody studied under a man in the English department out there and put me on to him. I took six courses and got the highest marks in all of them except from this man in English. I just got a "good" from him. I roomed with James Light at Ohio State; he also had gone to Peabody. Later he came to New York and got tied up with the "Provincetown Players." That was at the time O'Neill was there.

R.K.: Why didn't you stay at Ohio State?

K.B.: Well the family had moved to New York-our ideal was to get to New York anyhow. Westinghouse used to do a lot of subcontracting. Dad got in touch with an outfit they were connected with in Hoboken that was going somewhere-dealing in accessory parts of automobiles. He wrote to this company and told them they weren't handling their correspondence properly. The next thing I knew they invited him to New York. He sold himself on the damn job. We moved into Weehawken, above the Forty-second St. Ferry. We lived there for several years. Cowley tried to get me to go to Harvard where he was going. I went up there with him to see him once, but apparently they didn't take to me at Harvard.

R.K.: They lost.

K.B.: I started Columbia because it cost less money, and I was living at home and used to go over there; three cents to cross over on the ferry, a walk up Forty-second St., and then take the subway for five cents. I went to Columbia for a couple of years and I was a totally different dropout there. I dropped out for the simple reason that the courses I wanted I couldn't take because they were postgraduate courses. And postgraduate courses don't mean that they're harder, they just have things lined up for you to take. I'd already taken six years of Latin and I wanted to take Medieval Latin. Well, I couldn't do that because it was a postgraduate course. There also was some Greek anthology stuff that I wasn't allowed 
to take. I told my father that this wasn't my dish. I asked him to let me go down to the Village to continue my studies. I promised him I'd cook my own meals and have a hot one in the evening if he would give me enough to survive down there.

R.K.: He bankrolled you?

K.B.: Yes, a very small amount. And I worked; it didn't take me long to get mixed up and started.

R.K.: Where did you live in the Village?

K.B.: There was a triangular building right when you go from Twelfth St. out Seventh Avenue in Greenwich; it's torn down now. It was during the war and there was an Australian draft resister on the ground floor who played the piano. He gave us our music; he played Chopin. Stuart Davis, the painter, roomed in the building. On the top floor was Charlie Ellis; he married Norma Millay, Edna St. Vincent's sister. Berenice Abbott, the photographer, lived there as well. Djuna Barnes was there.

R.K.: Did you talk much to her?

K.B.: Yes, I was very taken with her niece. We used to play tennis. Jim Light and Sue Jenkins from my old high school were also there. Sue later married William Slater Brown, another twenties figure. Then there was Joe Gould - a fantastic creature. He lived on cigarettes and booze. And he bummed. When my Counter-Statement came out-it was a standard thing - he always shook you down. Joe came around when your new book came out. He was extremely bright; a wonderful guy in all kinds of ways. So he talked about the book, and discussed it in great length. We made a lot of nice wine at the time. I knew he was going to get sauced, but I always gave him some drinks. He kept talking about the book. And then he says, well, he finally says, "Well, I don't like to flatter someone whom I'm going to borrow money from. ..."

Joe was a very bright fellow, but half-cracked. He had a funny way, a big mouth. One time he came around and said he was thinking of marrying a Negress from Harlem; he said if he did he'd have to ostracize a great many people. He wrote in all kinds of little school books. I don't know where they all are. They all vanished. Some of them actually got published in The Dial, then they sort of vanished.

R.K.: What were you writing during those early days after you dropped out of college and moved to the Village?

K.B.: Well, at that time I was putting out squibs - little things for for- 
eign trade magazines. I learned a lot from Matty Josephson who worked with me. You could get funny little things from the Department of Commerce and write about a possible market for this or that. We did a lot of reviewing as well. There was a second hand store over on Fourth Avenue; they gave you twenty-five percent off list price of any book you'd review. R.K.: A few years after you moved to New York, you married Lily Batterham and moved out in the country, near Andover, New Jersey. How did you and Lily come to buy a place way out here?

K.B.: It was in 1922. Lily and I were visiting friends out here one weekend, and there was a house for sale near them. The place had two rooms. A worker on the roads lived there. There were no steps up to the door and the guy had been throwing tin cans out the back door for at least fifty years. The whole damn place was just a bunch of rotten tin cans. The inside was covered with newspapers - the walls were newspapers. There was a chicken with his head cut off bleeding on the floor. This was us, this was us! We got a deal on that place! We didn't have a cent, but we decided we'd like to live in the country. I borrowed three hundred bucks from my dad for the first payment and the mortgage. We made a deal for the place and seventy acres on the hillside.

R.K.: When was the house built?

K.B.: In 1857. It was well built; it had hand-hewn beams pegged and mortared in. It had a beautiful foundation and this wonderful frame. We got the whole thing, house and land, for fifteen-hundred dollars. I paid twenty-five dollars a month for five years and then it was mine. But, at the time, I asked myself: "For God's sake where are you going to get twentyfive dollars a month to pay that off, and feed the kids at the same time?" Shortly after that I sold a couple of things to The Dial. Then I got a note from them asking if I would be available to do some editorial work for six months while one of its staff was away. Of course I accepted the position. But we didn't even have a car back then. I would walk four and a half miles to the station and ride into New York City. It takes an hour and a quarter to get to town and across from Hoboken into the city. At that time The Dial was right across Thirteenth St. towards the end of Sixth Ave.

R.K.: Did you move into the house immediately?

K.B.: Very soon afterwards. The renter who was there left a bed in one of the rooms and asked if we would keep it in the basement until he had a 
chance to come and pick it up. We were afraid that it would be devil ridden with bedbugs - with a place like that you can be sure of it. But, we never saw any bedbugs. So we placed the bed in the basement. About fifteen years later when we were cleaning up the basement he still hadn't come for it. We figured he probably wouldn't be back and decided to burn it. We put the bed out on the lawn in the sun. In an hour we came back. My God, it was just crawling! You see there were wood tics in it. They were in his bed with him. Why should they go anyplace else? They lived in the wood. They live on wood. By God, they just eat. We burned that awful fast.

R.K.: So you lived here, walked to the station, and took the train into work at The Dial. Did you commute every day?

K.B.: Yes, I commuted every day. It cost seventeen dollars a month to commute back and forth. I was making fifty dollars a week working in The Dial office, which was pretty good back in those days. Think about that against paying seventeen dollars a month for the train ride. And I made more money on the train than I made in the office because I was doing a lot of translating and reviewing and such. I would write first drafts on the train, then my wife would type them up, and I'd work on those on the way back.

R.K.: You had both a wife and daughter to support by this time didn't you?

K.B.: I had the first daughter, yes. And shortly after that another turned up, Eleanor, and a third daughter a little later. The difference of the scale of living fifty miles from the city was a help. If you were living in the country then and getting your salary in the city, that was one big difference. By the end of the year, I'd put new walls on the house and bought a piece of land across the road so nobody would be in front of us. I never mortgaged the place; I paid it all off. And during the great smash in ' 29 we did fine. I was completely free. Everybody else had borrowed all the money they could to put in the damn stock market. I had bought a few stocks, but I bought them outright, not even on margin. I still have them! R.K.: You still have the stocks? But the point of owning stock is you're supposed to sell them.

K.B.: Yes, you're supposed to. But I just bought them. I've gotten a little income from them all these years.

R.K.: Who were your intellectual heroes at that time, in the twenties? 
K.B.: I was reading a great deal of French literature at the time. Earlier, one of the professors at Ohio State had put me on to Thomas Mann. I loved Death in Venice so much I made a translation for myself. I never did a thing with it, just put it in a drawer. Then I started doing a lot of translating for The Dial. I did all the Mann letters, some French work, and all kinds of translating. Scofield Thayer was going through Europe acting as a culture importer, picking up all kinds of stuff that would become famous. Gilbert Seldes, who was managing editor of The Dial then, told me that Scofield had cabled that we'd gotten the rights to Death in Venice. He asked what we might do about a translation. I told him, "I'll bring you one in the morning."

R.K.: How did you know German and French? From college?

K.B.: I studied them on my own. My accent was never very good. But, I really worked on translating. I would write the first draft just as it was in German or French, like "in the corner standing umbrella," or something like that. Then, I would lay the original aside, and take time to edit it. Then I'd get all of the other language out of it.

R.K.: That demands a lot of time.

K.B.: Yes, but poor translations make me furious. My friend Dell Hymes mentioned that he had gotten one of his books on social linguistics translated into Italian. I've never seen one of these Italian translations that wasn't done criminally. They just slap it down.

R.K.: Have you ever been to Europe?

K.B.: I was in Europe, yes. I was down in Italy, and a few days in Paris and then up and stopped in England.

R.K.: You've never been to the Northern Countries?

K.B.: No, that was the only time I was. No, one time I was in Barcelona. R.K.: When was that?

K.B.: That must have been twelve years ago or so. No, that must have been eight years ago. They had this kind of technological outfit. An enormous building, and they had the strangest damn thing, these chairs turning to the middle of this damn room. And they had these things hanging down like people hung in effigy. I couldn't make a damn bit of sense out of it; I couldn't get anybody to tell me what it was. It must have been some kind of suggestion that students were making about something or other, but I couldn't make it out. The most uncanny looking thing you ever saw. R.K.: And they flew you into Barcelona and flew you out. 
K.B.: Yes.

R.K.: And the other trip, when was that?

K.B.: They were both after Libby.

R.K.: You never went to Europe until you were in your seventies?

K.B.: The whole point is, this is a point of mine. The whole time I was building up this house around here, every goddamned week, I was getting ready to go to Europe but everything would turn up. I'd get another wall on the house or another kid would be born or I'd buy this or that. Kept putting it off. Finally, my God, I had enough money to go to Europe; we're all ready to go and off we go and by God they were all coming back. Hitler was changing the whole damn thing.

R.K.: Who's your favorite composer?

K.B.: Well, let's see. I don't know. My first - the one who made the biggest impression on me, I never got over was, of course, Chopin. Then I remember the one that nobody paid much attention to, what's his name, César Franck. I went through a terrific Wagner period. At one stage I was just nothing but music, living with music in New York, going to concerts every night. You see I got this job reviewing for The Dial and Paul Rosenfeld was doing the music for them. Paul used to take me to concerts every once in a while. Paul and Marianne Moore didn't get along very well in the sense that Marianne Moore would fight for a comma and so would Paul.

R.K.: You wrote a novel and some fiction early on and later lots and lots on theory. What is the difference for you between writing fiction and writing theory?

K.B.: What it is - I couldn't write any more novels; I could write poetry but I can't write another novel. I had to quit; I got into the damn thing. That's why I couldn't write my reminiscences either. I'm afraid to get into that. I'd get psychogenic asthma - get in there and never get out. I feel my theories of language are greatly affected by my responses to my own work. Several times in my life I've gotten into terrific jams and this is the result of self-hypnosis, the utter suggestion of my own goddamned language.

R.K.: You mean after a book appears, or when you're working on a book?

K.B.: Sometimes during, sometimes after, sometimes both. You can use your creation in various ways. I remember when I got in my troubles, I had a choice of going to an analyst or a priest; I couldn't go to either. I was 
too pigheaded. So I analyzed myself in my work. I presented the whole thing, all the things that I wrote about, and I saw something of what was eating at me. Whether rightly or wrongly, I could see what was going on in my life. Once you get that sort of attitude you can transform something and see if you can work with it in a different way.

R.K.: Your "troubles" were in the early thirties when you were writing your novel before your divorce from Lily?

K.B.: Yes. Much later I started another novel; it was absolutely insane. I was just crazy. The characters weren't even figures, they were just sort of big blotches running around. I was into a horrible finish, so I just threw it away. If somebody else can write a novel and not do himself any damage, well all right then, that's his business. But, if you find you're in trouble or something like that, then I'm just through with it. Sylvia Plath worked her problem in a particular way. The fact is you can work it in two ways: you can work it, but also work out ways to counteract it. She found out that the best lines she wrote were the ones that were the most suicidal, so she ended up specializing in her suicidal mind. She focused on those things that completely hypnotized her along this suicidal line, then she could work in ways of getting back at Ted for doing various things. It's like in Japan where you kill yourself at the doorstep of your enemy.

R.K.: When did you get over your "troubles"?

K.B.: I don't know that I ever did. The only thing is that you know now all the times when you think you're going crazy. At least I've gone eightythree years without getting into the nut house.

R.K.: That was fifty years ago. Did you turn to alcohol then?

K.B.: Alcohol wasn't bad. I wouldn't turn against alcohol; not by a damnsight. As a matter of fact, I actually quit a couple of times. But, it made me feel as though I had sinned. I was ungracious to a kind thing. But I had to go easy on it.

R.K.: Did you ever write under alcohol?

K.B.: No. I believe like Sinclair Lewis - slap it out when you're healthy. I think Faulkner's style is alcoholic. I think it would be better if it weren't. He just rolls on too much; he just spills out. He's like Wolfe in that sense; Wolfe's pretty alcoholic. I think a certain amount of it is all right. I used to write occasionally just before going to bed, when I was tired and had had some drinks. But I'd nearly always throw it away.

R.K.: Now, four of your five children live in New York City; why don't 
you live in New York, or at least join them in the wintertime?

K.B.: Well, I hate-I like - I loved the town. When I came to New York it was a dream; it was just lovely. But I think now it's just pollution, pollution everywhere you turn. Every damn city in the country is that way now. Everywhere I go I see it. The irony is that I started out all this work on ritual pollution in Greek tragedy. I end up with pollution in New York, New Jersey, everywhere. The most real pollution. You can sense it in the water.

R.K.: Do you have pollution in Andover.

K.B.: No, not in the water here. This is the way God made water here. Down the line in New York City is the way man makes water.

R.K.: When did you get electricity here?

K.B.: Well, let's see.

R.K.: Michael, your son, told me the late fifties.

K.B.: Whatever he said is it.

R.K.: I just thought I'd check.

K.B.: Oh I know, that's when we put the plumbing in the house. We put the plumbing in not long before Libby died. We needed it for her. Earlier we were very . . . it was a matter of scruples with me.

R.K.: Scruples, why?

K.B.: The amazing story about that, when we had all this old-fashioned plumbing, Garden of Eden plumbing, when Michael graduated from the local high school we had a big meal for all of his schoolmates. We put on a big show, in that old place up there we had that big oak room. They had balconies in there. We had a big meal for them, and they had stuff down at the barn and this and that. Finally one of the girls said, "I can't understand it, valedictorian of his class and no plumbing."

R.K.: You said scruples, what does that mean? Was it better to live that way?

K.B.: Harry [Chapin, his grandson the singer] had some people out here in the summer, out in the barn, and he had a psychologist who was going to take the place in the summer. Finally the psychologist said no, that wouldn't be good for his child, to confront that.

R.K.: And you thought it would be good for the child.

K.B.: Well yeah, reality, reality, reality, give the kid reality. My whole theory was that it's a real confrontation that's right. I think the whole goddamned society is run-down idealism, just out of sight out of mind 
... I think its basic lies ... damnation.

R.K.: Where's the Calder sculpture from the outhouse?

K.B.: Oh, the kids have that hidden somewhere. You know what it is, it's a big hand with one middle finger for the roll.

R.K.: To put the toilet paper on. But you still use it? You use your plumbing?

K.B.: My God what you did do. ... Your body does learn, I mean it was damn seldom that I had to go out there at night and in the winter. God, it was hell. But your body learns. All you have to do is be careful - don't eat a lot of fruits at four in the afternoon or you're out of luck.

R.K.: Let me go back to living here. What time do you get up in the morning? How do you organize your day?

K.B.: Quite often, during the week, I get up at six and listen to the news. I get the news on my radio. This morning I got up at six and started listening to the radio. At eight I realized I hadn't heard a goddamned thing; I fell back to sleep again.

R.K.: Does the news come from New York City?

K.B.: Oh yes, I get much better reception here than most people get in New York.

R.K.: On a normal day you usually get up and listen to the news and then what do you do?

K.B.: Well, I usually get up between seven and eight o'clock. I usually go to bed around eleven-thirty and take an hour or so to get to sleep.

R.K.: Do you still have insomnia?

K.B.: Not so badly as I did, but I still have it. It's eased up a lot.

R.K.: What's your insomnia about?

K.B.: I never figured it out. In the old days it was a very fortunate thing to have; I got more work done. As a result of my insomnia, I could write like the devil.

R.K.: Do you think you were too intensely wrapped up in your writings, that's why you couldn't sleep?

K.B.: Partly that, but it wasn't only that. I was always in a hell of a mess when I was younger; I was always fighting on about five or six fronts at once.

R.K.: When in the day do you write?

K.B.: I do most of my work in the morning. I used to, as I say .... In the old days I worked morning, afternoon, evening, and night. I got a lot of 
work done that way, but I can't do that anymore. What you find is you're just too tired to work, and yet you just waste too much time. When I first wrote, I used to have a wonderful trick of planning what I was going to do the next morning, go to sleep and then do it. But I found I had to quit that because I'd just never turn it off. Then I had to start to waste time. R.K.: So, you don't read to go to sleep.

K.B.: No, I can't read to go to sleep-never worked.

R.K.: What project are you working on now?

K.B.: I'm still clarifying my work on human symbol-using. I've reduced much of my thinking in this area to a formula: What we are is bodies that learn language.

R.K.: All your work reduced to a formula?

K.B.: Yes, but you build from the formula. I don't reduce and stop there. This formula gives me four different motives. The first is to be a body. This includes motives that you get from the body; for instance, at a certain age you begin to develop sexual interests that the body wouldn't think of earlier. The second type of motive derives from language and symbol use; this includes all my analysis of the way we use language and language uses us. The third is a post-Freudian sort of motive having to do with the fact that we learn language very early in our development. We are born speechless and learn language at the most immature stage of our lives. And, at this time, we discover the "magic" words can do. The words "taste of an orange" can take the place of the sensation for the taste of an orange. Finally, the fourth type of motive is stimulated by the attention and communication language makes possible - the accumulation and distribution of instrumental devices, especially technology. Our language gives us technology. We are the only animals on earth with this peculiar type of symbol system and therefore the only animals with technology. Animals may have little development of tools, but they are tropisms, and their "developments" are not passed on.

In an essay of mine, "The Definition of Man," I have a little anecdote: I saw this wren out here on the porch. He was absolutely sui generis, no question about it. When they get all the young out of the nest, they have to keep coming back and wheeling and banging until they can get 'em out. Well, they were all gone for about a week, but this one guy still stayed on there. Then one day that parent came out there, and this fellow had his mouth open. Instead of feeding it, the parent grabbed his beak and pulled 
him out that way. He used the principles of leverage. That's a tremendous invention. My notion is that he wouldn't have ever done it himself again. Or, even if he did, he had no way of telling other wrens how to do it. So language makes it possible for you to tell many things that you found out for yourself, that you can tell people about. It's tremendous, and I think technology is developed largely by that business.

I imagine if you watched animals you'd find that they all have little developments of tools, but that's the end of it. All they ever do is tropisms. It's just spontaneous. It's the difference between the way a beaver makes a dam and a human being makes a dam.

R.K.: A tropism means an instinctual response?

K.B.: Yes.

R.K.: Rather than an intelligent response?

K.B.: Yes. Animals use tropisms which get them doing the same thing over again. Humans use tropes which are innovative, allowing us to develop new twists. My stress on the innovative puts me at odds with the behaviorists; my big battles are with them. I love to fight the behaviorists. The point is that I'm a behaviorist. I have to make a very distinct line between me and the others because I've come so close to them. Permanence and Change and my Grammar are built on a whole group of behaviorists who have moved on since then.

R.K.: Your recent work has concerned logology.

K.B.: Yes. I was giving a lecture at Notre Dame a few months ago. I have an interesting relationship there. I've done a lot of work on theology-I secularize that; I don't follow it literally. What I had to do there was explain that my theory of language had nothing to do with the truth or falsity of theology either way. I talk about language, whether it came from God or the devil. Language, then, is reduced to two kinds of culmination. In theology, the culmination is in the realm of the supernatural. The language itself gives you all your theology; you couldn't have theology without language. Faith comes from hearing. You couldn't have doctrine without language. That gives you your whole notion of ultimate supernature-the nature of the supernatural. Then, technology gives you the nature of counternature. The more technology we get, the more counternature develops in response to it, as an adaptive behavior in us. Marx and Engels say the very same thing, that man has departed from his natural conditions. We can't get out of nature, but we can make nature do things 
through our technology; and technology produces counternature.

R.K.: Why is it "counternature" instead of "second-nature"?

K.B.: Oh, if you want to have another word for it; but what I'm getting at is that it brings up a totally different set of conditions from the ones that you would confront without that. For instance, take an automobile. We were able to survive earlier natural conditions to the point where we could produce automobiles. The first thing that follows from the development and use of the automobile is that it ruins our ability to walk. It turns the whole damn thing around. Every time you produce something with a machine, it cripples you from this standpoint.

R.K.: You've always been antitechnology.

K.B.: It's not that simple. For a long time I thought that environmentalism was antitechnological. But, if you want to criticize technology, you've got to find someone with technological expertise to prove your point-like showing scientifically that the environment has been harmed. Environmentalism becomes technology's criticism of itself.

R.K.: What do you plan to work on in the future?

K.B.: I've gotten away from literature, and I plan to go back and work on that. I've got quite a bit of stuff on Whitman, and I think I ought to finish that up. Also, I have a lot of material on Macbeth that I'd like to finish. R.K.: You've never done Macbeth?

K.B.: Never. I had notes on it as well as on several of Shakespeare's other plays that I haven't filled out. Including that stuff, I have at least four books in manuscript form right now.

R.K.: Some of your greatest essays have been, for me, on Shakespeare's plays. What are the other books?

K.B.: One of them is The Book of Devices. Then there's the new edition of Counter-Statement. Then there's the Symbolic book that they want me to finish, though it's all published in little quarterlies and so on. And there's a book on logology still to come-three talks, language and psychology, language and sociology, and language and technology. Cowley thinks that as soon as I finish all of this stuff I'll drop dead. 